\title{
Analysis of EU Regulation 2019/933 on the SPC Manufacturing Waiver Exception
}

\author{
Miguel Vidal-Quadras
}

Published online: 9 September 2019

(C) The Author(s) 2019

\begin{abstract}
At the end of May 2018, the European Commission published a proposal for a Regulation amending the SPC Regulation to introduce a specific new exception that has been called the manufacturing waiver. The objective of this Regulation is to boost the European generic and biosimilar industry and make it competitive in relation to third-country competitors and in other markets. There were three aspects of the initial proposal that could have jeopardised the objective of the new legislation: its application was deferred for up to 15 years, the exception to manufacturing was only for export and not to enter the EU market after the expiry of the SPC, and the existence of safeguards that would have forced the maker to provide sensitive confidential business information. The European Parliament and the Council were sensitive to all these limitations and proposed an important revision of the text which was finally approved as Regulation (EU) 2019/933. This article explains the rationale behind the legislation and the modifications that have been introduced in the final text, which was approved on 20 May 2019 and entered into force on 1 July 2019, to achieve the objectives pursued.
\end{abstract}

Keywords Supplementary protection certificate - SPC · Manufacturing waiver . Export exception · Stockpiling

\footnotetext{
Dr. Miguel Vidal-Quadras is a Certified Senior Lecturer in commercial law and protection of technology at the University of Barcelona and at the Universitat Internacional de Catalunya, Barcelona, Spain. He is also an attorney-at-law and founding partner of Vidal-Quadras \& Ramon.
}

M. Vidal-Quadras (凶)

$\mathrm{PhD}$ in Law; Certified Senior Lecturer in Commercial Law and Protection of Technology, University of Barcelona and the Universitat Internacional de Catalunya, Barcelona, Spain e-mail: m.vidalquadras@ vidalquadrasramon.com 


\section{Introduction}

On 28 May 2018 the European Commission launched a Proposal for a Regulation of the European Parliament and of the Council amending Regulation (EC) No. $469 / 2009$ concerning the supplementary protection certificate for medicinal products. ${ }^{1}$ By means of this proposal the European Commission submitted to the Parliament and the Council the creation of a new exception to the infringement of an intellectual property right, specifically to the Supplementary Protection Certificate or SPC. The new exception is known as the manufacturing waiver, ${ }^{2}$ since it would permit manufacturing a protected technology with the exclusive aim of either exporting to third countries or entering the market right after the expiry date of the SPC. This proposal to amend the SPC Regulation has been both warmly welcomed and sharply criticised by the pharmaceutical industry. ${ }^{3}$ The big pharmaceutical companies in the United States are opposed to the new Regulation, as they consider that it will be detrimental to their interests, especially in growing sectors such as biotechnology. The manufacturing waiver will allow European market players to access the market in the United States, now closed to their industry, as well as the European market itself, which they are forced to enter later as a result of not being able to start manufacturing before the SPC expires. ${ }^{4}$

\footnotetext{
${ }^{1}$ Published as COM(2018) 317 final, 2018/0161 (COD).

${ }^{2}$ In its "Communication to the European Parliament, the Council, the European Economic and Social Committee and the committee of the Regions (2015), COM(2015) 550 final, Upgrading the Single Market: more opportunities for people and business", the Commission stated that "[t]o strengthen EUbased manufacturing and competitiveness in industry sectors whose products are subject to regulated market authorisations, the Commission will explore a recalibration of certain aspects of patent and SPC protection. An SPC manufacturing waiver could allow the European generic and biosimilar medicines industries to create thousands of high-tech jobs in the EU and many new companies" (published at: https://ec.europa.eu/transparency/regdoc/rep/1/2015/EN/1-2015-550-EN-F1-1.PDF. Accessed 31 March 2019). Thyra De Jongh, Alfred Radauer, Sven Bostyn and Joost Poort, a team of the Technopolis Group, explained in the report "Effects of supplementary protection mechanisms for pharmaceutical products" of May 2018 that "[i]n 2015, the Commission issued a communication in which it expressed its intent to consider the introduction of a targeted SPC manufacturing waiver for export purposes. Rationale for this waiver is that, as long as SPC protection on the reference product is still in force in European markets, manufacturers of generics or biosimilars are not allowed to produce in EU Member States. This is said to put EU-based manufacturers at a disadvantage compared to non-EU-based operators. The waiver is primarily intended to promote Europe-based manufacturing, and thereby accelerate access to generic products for European consumers, but is also hoped to have a knock-on effect on innovation by promoting increased investment in high skill jobs in Europe" (published on 15 June 2018 and available at: http:// www.technopolis-group.com/wp-content/uploads/2018/06/2718-Technopolis-report-on-supplementaryprotection-mechanisms.pdf, p. 86. Accessed 31 March 2019).

${ }^{3}$ See the comments of Medicines for Europe, representing the interests of generic and biosimilar companies in the European Union at: https://www.medicinesforeurope.com/news/spc-manufacturingwaiver-moves-a-step-closer-as-influential-european-parliament-envi-committee-supports-reform/ (accessed 30 January 2019); and EFPIA, representing the interests of pharmaceutical companies, including the main United States' corporations, in the articles "European pharma body criticises SPC waiver vote", of 6 December 2018, at: https://www.lifesciencesipreview.com/news/european-pharma-body-criticisesspc-waiver-vote-3290?utm_source=World+IP+Review\&utm_campaign=7d529fcd9f-LSIPR_Digital_ Newsletter_31_05_2018_COPY_01\&utm_medium=email\&utm_term=0_d76dcadc01-7d529fcd9f27088365 (accessed 30 January 2019).

${ }^{4}$ The concern regarding the effect that this Regulation may have on competition not only between originators and generics and biosimilars but also between European and US industry is expressed in some
} 
The Commission explained in its Proposal for a new Regulation that the absence of this exception in the SPC Regulation had two unintended consequences: ${ }^{5}$

(1) It had prevented manufacturers (or "makers" in the final text of the Parliament and the Council ${ }^{6}$ ) of generic and biosimilar medicaments established in the Union from manufacturing, even for the purpose of exporting to third-country markets in which such protection does not exist or has expired (the European Parliament and the Council added that: "Likewise, they are prevented from making for the purpose of storing for a limited period before the expiry of the certificate"); and

(2) It had made it more difficult for those manufacturers (makers) to enter the Union market immediately after expiry of the SPC, given that they were not able to build up production capacity ("for export and for the purpose of entering the market of a Member State" as the Parliament and Council added to the text of the proposal) until the protection provided by the certificate had lapsed, by contrast with manufacturers located in third countries where protection does not exist or has expired.

The European Commission was clear when it concluded that this "puts manufacturers of generics and biosimilars established in the Union at a significant competitive disadvantage compared with manufacturers based in third countries that offer less or no protection" and that if the European institutions did not intervene, the viability of the generic and biosimilars industry in the EU could be under threat. ${ }^{7}$

\footnotetext{
Footnote 4 continued

articles published to date. In an article published in Nature Biotechnology (Vol 37, No. 1 (January 2019), pp. 21-22), "An export-only exception to pharmaceutical patents in Europe: should the United States follow suit?", Timo Minssen, Aaron S. Kesselheim and Jonathan J. Darrow explained that: "The brandname industry's trade group has predictably objected to the proposed exception, asserting that the proposal reduces IP [intellectual property] rights and thereby jeopardises patient access to innovative treatments". Behind these fears is the possibility that "US legislators, motivated in part by concern that the EU proposal might incentivize US manufacturers to shift capacity abroad and lead to a loss of jobs and tax revenue, could provide similar exceptions for export activities in this country". The title of the article, "Should the United States follow suit?", extracts the idea expressed in the last sentence of the article and shows how visceral is the opinion of certain interests, which place more emphasis on threats than on the legal arguments.

5 See Recital 4 of the Proposal.

6 The final text of the European Parliament and the Council included a definition of "maker" in Art. 1, letter (f) of the 469/2009 SPC Regulation, in which it is provided that "'maker' means the person established in the Union on whose behalf the making of a product or a medicinal product containing that product, for the purpose of export to third countries or for the purpose of storing, is done".

7 Recitals 5 and 6 of the Proposal (the initial reference to "manufacturers" has been changed to "makers"). The Parliament and the Council strengthened the arguments of the Commission by adding to Recital 5 that: "The Union should strike a balance between restoring a level playing field between those makers and ensuring that the essence of the exclusive rights of holders of certificates ("certificate holders') is guaranteed in relation to the Union market", and to Recital 6 that: "That situation could affect the fully effective functioning of the internal market through the loss of potential new business opportunities for makers of generics and biosimilars, thereby possibly diminishing related investments and hampering job creation within the Union". A new Recital 7 was added to emphasise the importance of the timely entry of generics and biosimilars to reduce prices and to ensure better access to affordable medicines in the EU.
} 
The European Union has already harmonised patent law so as to make it possible that the pharmaceutical laboratories can obtain marketing authorisations for medicinal products before a patent expires. This enables them to enter the market right after the expiry of the patent. The European countries have expressly included in their legislation that the request or award of a marketing authorisation is not to be regarded as patent infringement. This extensive "Bolar" provision has permitted European makers to obtain marketing authorisations not only in the European countries, but also outside the borders of the European Union. However, this legal framework does not enable a European maker to market its pharmaceutical product in a certain country once the patent or SPC has expired in that country. If the patent or SPC is still in force in the European country where the manufacturer intends to produce the medicine, the manufacturer will be at risk of patent infringement in that country although the patent has expired in the country of export.

The amending Regulation proposed by the European Commission and adopted by the Parliament and the Council of the European Union will enable European manufacturers to be competitive abroad and in the European territory after the expiry of an SPC. This new legislation, approved as Regulation (EU) 2019/933 of the European Parliament and of the Council of 20 May 2019 amending Regulation (EC) No. 469/2009 concerning the supplementary protection certificate for medicinal products ${ }^{8}$ will allow the production of a medicine for which a marketing authorisation has been obtained in a third country despite the existence of an SPC in the country of manufacture.

The new legislation is analysed below to verify if the proposal of the Commission satisfied those objectives. This study will examine what aspects were to be modified to make the proposal a real and effective instrument to boost the competitiveness of the European pharmaceutical industry of generics and biosimilars in order to compete under equal conditions with manufacturers established in third countries and to what extent the intervention of the European Parliament and Council have allowed these shortcomings to be overcome.

\section{Background and Previous Proposals to Regulate the Export Manufacturing Waiver}

When the European Commission proposed the new Regulation, it aimed (a) to ensure that manufacturers (makers) established in the Union were able to compete effectively in third-country markets where supplementary protection did not exist or had expired, (b) to put those manufacturers (makers) in a better position to enter the Union market immediately after expiry of the relevant SPC, and (c) to serve the aim of fostering access to medicines in the Union by helping to ensure a swifter entry of generic and biosimilar medicines onto the market after expiry of the relevant certificate. ${ }^{9}$

\footnotetext{
8 OJ L 153, 11 June 2019, pp. 1-10.

9 Recital 7 of the amending Regulation as originally drafted (final Recital 8). For a thorough analysis of previous attempts and the economic and legal background of the manufacture for export exception, see Seuba, Genovesi and Roffe (2017).
} 
The proposal of the Commission was not the first text of a specific exception in this domain to be discussed in the European Union. However, it was the first time that the Commission boosted an exception to manufacturing activities within the scope of protection of a European intellectual property right such as the SPC.

In 2003 European institutions proposed for the first time that the manufacturing of a pharmaceutical product should not be considered a patent infringement in certain circumstances. Only three years before, the Commission had lost its battle against the Canadian Bolar exception. The Commission, through its proposal to modify Directive 2001/83, ${ }^{10}$ included a Bolar-type provision in the text of the Directive. ${ }^{11}$ In its revision of the text, the European Parliament added a further amendment to the proposal of the Directive of the Commission and suggested the inclusion of an exception to patent infringement that comprised not only obtaining a marketing authorisation, but also exporting to third countries. ${ }^{12}$ The justification given by the European Parliament in 2003 was that it was intended to facilitate the export of generics. ${ }^{13}$

The Commission did not accept the proposal and sent it back to the European Parliament without the export exception. In its second report to the proposal of the

\footnotetext{
${ }_{10}$ Proposal for a Directive of the European Parliament and of the Council amending Directive 2001/83/ EC on the Community code relating to medicinal products for human use (COM(2001) 404 final 2001/0253(COD)), published in OJ C 75E, 26 March 2002, pp. 216-233.

11 The text introduced by the Commission included a new Art. 10(4): "Conducting the necessary tests and trials with a view to application of paragraphs 1,2 and 3 to a generic medicinal product shall not be regarded as contrary to patent rights or to complementary protection certificates for the medicinal products".

12 Report of the European Parliament of 9 October 2002 on the proposal for a European Parliament and Council Directive amending Directive 2001/83/EC on the Community code relating to medicinal products for human use (COM(2001) 404 - C5-0592/2001 - 2001/0253(COD)). Amendment 39, Art. 1(7), to Art. 10(4) of Directive 2001/83/EC. The text of the proposal was drafted in the following terms as a new Art. 10(4) to Directive 2001/83/EC: "Conducting the necessary tests and trials [on the active ingredient, submitting an application for marketing authorisation for a generic or biosimilar medicinal product, submitting samples pursuant to Article 19 and granting marketing authorisation for a generic medicinal product] with a view to application of paragraphs 1, 2 and 3, [as well as for export, will not be regarded as contrary] to patent rights or to complementary protection certificates for [the reference] medicinal products [in question]".

13 The justification given by the European Parliament (see supra note 12) was that: "This amendment makes the Commission proposal more precise in that it describes exactly what development work may be carried out in connection with the authorisation procedure for a generic medicinal product. This will create legal certainty. Otherwise, generic medicinal products will continue to be developed outside the EU while the original is still under patent, with the consequent loss of jobs, investment and know-how. A provision concerning exportation has been introduced for the following reasons: to improve access to medicinal products by facilitating exports of generic products so as to meet the health needs in a country which has granted a compulsory licence or which does not have a patents system".

Four years later, in 2006, a Regulation on compulsory licences on patents for generics for export to countries with public health problems was established, thus giving a timid answer to a necessity but not to the competitive interests of the generic and biosimilar industry outside the European Union (Regulation (EC) No. 816/2006 of the European Parliament and of the Council of 17 May 2006 on compulsory licensing of patents relating to the manufacture of pharmaceutical products for export to countries with public health problems, published in OJ L 157, 9 June 2006, pp. 1-7).
} 
Directive, the Parliament insisted on the introduction of that exception, now Art. $10(5) .^{14}$

Again, the Commission did not consent to the export clause. Whereas, in a common position, the European Parliament and the Council reached an agreement pursuant to which the Bolar clause was accepted, the export clause did not make its way into the text. ${ }^{15}$

Fifteen years after that first proposal of the European Parliament, the European Commission came to accept the export clause, albeit limiting its application to SPCs.

In Spain, a new Patent Act was passed in $2015 .^{16}$ Some political parties had proposed an amendment to the Act intended to introduce an exception to patent infringement, namely the manufacture-for-export exception. ${ }^{17}$ Ultimately, the Spanish Government did not support these proposals and the amendments were rejected. As the adoption of an exception allowing the manufacture for export of medicines was under discussion in the European institutions, it was considered that the question should be treated in that context.

One year later, a comprehensive economic and trade agreement was concluded between the EU and Canada. In fact, that agreement enacted the manufacture-forexport exception, in quite similar terms to those of the Regulation approved by the

\footnotetext{
${ }^{14}$ Recommendation for Second Reading, of 2 December 2003, on the common position adopted by the Council with a view to adopting a European Parliament and Council Directive amending Directive 2001/83/EC on the Community code relating to medicinal products for human use (10950/03/2003 - C50464/2003 - 2001/0253(COD)). The text said: "Conducting the necessary studies and trials with a view to the application of paragraphs 1, 2 [and] 3 [to a generic medicinal product] and [paragraph 4] to a [biosimilar] medicinal product and the consequential practical requirements [relating to those provisions, as well as for export,] shall not be regarded as contrary to patent rights or to supplementary protection certificates for those medicinal products".

15 Common Position (EC) No. 61/2003 of 29 September 2003 adopted by the Council, acting in accordance with the procedure referred to in Article 251 of the Treaty establishing the European Community, with a view to adopting a directive of the European Parliament and of the Council amending Directive 2001/83/EC on the Community code relating to medicinal products for human use, number 11 . This agreement between the two European institutions gave the green light to the so-called Bolar clause.

${ }^{16}$ Approved by the Cortes Generales (Congress and Senate) on 24 July 2015 as Act 24/2015.

${ }^{17}$ Specifically, the Catalan main party at that time, Convergencia $i$ Unió, suggested the following draft: "The rights conferred by the patent shall not extend to the manufacturing or using of the invention or the offering or delivering of the means needed to carry out the invention in Spain, with the aim to dispose of the subject matter of the invention in the market immediately after the expiry date of the patent and/or if the offering or selling has as the final destination a country where patent protection does not exist" (Amendment No. 79).

This proposal for the implementation of an exception to infringement contained two provisions that preserved the possibility of manufacturing during the SPC period with two different aims: (a) to satisfy the necessity of export to third countries where there is no patent protection, and (b) to allow a medicines manufacturer or laboratory to enter into the market on day one after the expiry date of the SPC. In both cases the exception helps the manufacturer to compete on equal conditions with those located outside the territory of the EU.

Other political parties also supported the approval of an exception to export activities and proposed further amendments in that same sense. In the Congress Izquierda Unida, and in the Senate, together with the latter political party (amendment 11), Esquerra Republicana de Catalunya (amendment 38), Entesa pel Progrés de Catalunya (amendment 107). The other amendments proposed were limited to the export manufacturing exception (published on 3 July 2015 in the BOCG, Serie A, Proyectos de Ley, No. 555, pp. 184-262).
} 
Commission on 28 May 2018 to amend the SPC Regulation for medicinal products. ${ }^{18}$

\title{
3 The Comprehensive Economic and Trade Agreement with Canada and the Studies Commissioned by the European Union Prior to Proposing a Regulation to Be Applied Throughout the Territory of the Union
}

\author{
The Comprehensive Economic and Trade Agreement (CETA), signed on 30 \\ October 2016, is a free-trade agreement reached between Canada, the European
}

\begin{abstract}
18 The export to third countries in relation to contributory infringement has been expanded recently in the United States to encompass extraterritorial activities, including lost profits (WesternGeco LLC v. ION Geophysical Corp., No. 16-1011, 138 S. Ct. 2129 (2018)), contrary to how regulation on exports has been regulated and interpreted in the countries of the European Union. $C f$. the regulation in the United Kingdom, where indirect or contributory infringement is contemplated under section 60(2) of the English Patents Act 1977 which states that a person infringes a patent if he or she supplies or offers to supply in the United Kingdom, the means relating to an essential element of the invention, for putting the invention into effect when the person knows that those means are suitable for and intended to put the invention into effect in the United Kingdom. As for Germany, in principle, export of materials manufactured in the country for putting in practice the invention outside the territorial scope of the patent would not be included in the ius prohibendi of the exclusivity. Jochen Pagenberg, "Comment to The Wellcome Foundation Ltd. v. The Commissioner of Patents", 15 IIC 224 (1984), said that "the supplier of the substance in question must at least be aware that the receiver could thereby commit an infringement "for putting the invention into effect within this territory' (see Art. 30 of the Luxembourg Convention whereby the receiver can still reconsider whether he will actually commit the infringement. [...] To this extent, the adjudication of the scope of protection, as implied in the decision of the BGH, seems to extend beyond the limits of indirect infringement drawn by the legislature. [...] The infringement of a process invention [...] is only to be found if the process is used within the protected territory [...]. This is also assumed by Bruchhausen in Benkard concerning Sec. 10 Patent Act, marginal note 18, who expressly points out that materials for use in the invention abroad which are delivered from the Federal Republic of Germany are not covered by Sec. 10", p. 233. See also Benkard (1981).
\end{abstract}

According to the German Federal Supreme Court (judgment of 30 January 2007, Funkuhr II, case X ZR 53/04, 2007 GRUR 307), there would be indirect infringement if a company established in Germany supplied an essential element of the invention for export abroad in order to be assembled into the patented product knowing that the assembly will then be imported into Germany. It would entail that the export for assembly into the patented product abroad would not constitute an indirect patent infringement. The German Group of the AIPPI stated in its Report Q204 on "Liability for Contributory Infringement of IPRs" that: "The wording of the law does not explicitly require that the person offering or supplying the means must know that the use of the invention intended by the recipient is to be in that country. As far as one can tell, the Federal Supreme Court has not yet ruled explicitly on whether the assumption by the person offering or supplying the means that the invention is intended to be used in a different country excludes any contributory infringement. However, in its Funkuhr II (Radio clock) decision (BGH, GRUR 2007, 313), the Federal Supreme Court states that the specified offence of contributory infringement within the meaning of Section 10 Patent Act is intended as a precautionary measure to prevent any endangerment to domestic patent rights, independently of the actual place where the protected object is produced. In other words, a contributory infringement is also present when patent-free means (relating to an essential element of the invention) are supplied to a foreign country, if the supplier knows or it is obvious from the circumstances that the customer will import objects which are produced using said means and which infringe the IPR to the domestic country" (https://aippi.org/download/commitees/204/ GR204germany.pdf, accessed 29 January 2019). The text of the German Patent Act on contributory infringement is the same as that contained in the French or the Spanish laws on Patents (Art. L613-4 Code de la Propríeté Intellectuelle, Art. 60 of the Spanish Ley de Patentes). 
Union and its Member States. ${ }^{19}$ The Agreement has been provisionally applied, so the treaty has abolished customs duties on $98 \%$ of the types of product that the EU trades with Canada. ${ }^{20}$

Article 20.27 of CETA establishes the obligation of granting specific sui generis protection for pharmaceuticals. This is a type of protection that has existed in Europe since 1992, through the SPC. ${ }^{21}$ In Europe this certificate was valid for a maximum period of five years, while in Canada there was no regulation on such a specific kind of intellectual property right that permitted the extension of the protection of patents related to medicines.

The parties agreed that the duration of the sui generis right of exclusivity would not exceed a period of two to five years, at the choice of each party. ${ }^{22}$ It was also agreed that parties could introduce a limitation to that IP right related to the activities carried out with the protected product during the period of protection for the purpose of export.

The Canadian Patent Act was modified through Bill C-30 on 31 October 2016, ${ }^{23}$ just one day after the signature of the Agreement with the European Union and the Member States. Among other changes, the new Arts. 104 to 122 were added to regulate the new Certificate of Supplementary Protection or CSP. According to Art. $116(3)$, the term of the certificate in any event is for a maximum of two years, the minimum term foreseen in the CETA.

In relation to the exception provided to manufacturers during the certificate's term, Art. 115(2), with the title of "No infringement - export", foresees that: "Despite subsection (1), it is not an infringement of the certificate of supplementary protection for any person to make, construct, use or sell the medicinal ingredient or combination of medicinal ingredients for the purpose of export from Canada". Subsection (1), on the scope of supplementary protection, provides that it grants

\footnotetext{
19 The European Parliament approved the Agreement on 15 February 2017, P8_TA(2017)0030. EUCanada Comprehensive Economic and Trade Agreement. European Parliament legislative resolution of 15 February 2017 on the draft Council decision on the conclusion of the Comprehensive Economic and Trade Agreement (CETA) between Canada, of the one part, and the European Union and its Member States, of the other part (10975/2016 - C8-0438/2016 - 2016/0205(NLE)).

${ }^{20}$ Guide to the Comprehensive Economic and Trade Agreement (CETA), published at: http://trade.ec. europa.eu/doclib/docs/2017/september/tradoc_156062.pdf (accessed 2 January 2019).

21 In 1996 SPCs were also foreseen for plant products through a new Regulation, namely Regulation (EC) No. 1610/96 of the European Parliament and of the Council of 23 July 1996 concerning the creation of a supplementary protection certificate for plant protection products (published in OJ L 198, 8 August 1996, pp. 30-35).

22 Article 22.27(6) of CETA establishes that it is "without prejudice to a possible extension of the period of sui generis protection by a Party as an incentive or a reward for research in certain target populations, such as children". In the case of the European SPCs this additional extension is of six months according to Regulation (EC) No. 1901/2006 of the European Parliament and of the Council of 12 December 2006 on medicinal products for paediatric use and amending Regulation (EEC) No. 1768/92, Directive 2001/20/EC, Directive 2001/83/EC and Regulation (EC) No. 726/2004, published in OJ L 378, 27 December 2006, pp. 1-19.

23 Passed on First Reading by the House of Commons of Canada as Bill C-30, An Act to implement the Comprehensive Economic and Trade Agreement between Canada and the European Union and its Member States and to provide for certain other measures, on 31 October 2016.
} 
the same rights, privileges and liberties that are granted by the patent set out in the certificate, but only with respect to the making, constructing, using and selling of any drug that contains the medicinal ingredient, or combination of medicinal ingredients, set out in the certificate, by itself or in addition to any other medicinal ingredient.

In Europe, the DG Internal Market, Industry, Entrepreneurship and SMEs (DG Growth) commissioned a consultancy, Charles River Associates, to conduct a study to assess the economic impact on the European pharmaceutical industry, as well as wider impacts on employment and spending on pharmaceuticals, of a number of changes to exemption provisions during the patent and SPC term in Europe on medicines for human use, specifically related to (a) Bolar provisions, (b) exports during the term of protection, and (c) stockpiling for granting a day-one entry into the respective markets of the Member States. The opinion was issued in February 2016 and published by the European Commission on 5 October 2017 with the title of "Assessing the economic impacts of changing exemption provisions during patent and SPC protection in Europe". ${ }^{24}$

The conclusions of the report were clearly reflected in the Executive Summary of the report. ${ }^{25}$ The SPC export waiver and the day-one launch would bring clear benefits to the European pharmaceutical industry. ${ }^{26}$

It is also explained that the exemption would result in an increase in exports of the EU pharmaceutical industry of 6 to $18 \%$ and, if the day-one entry were introduced, savings on pharmaceutical expenditure of 1 to $4 \%$.

\section{The SPC as a sui generis IP Right Neither Regulated in the TRIPS Agreement Nor in Most Countries}

The SPC is a sui generis exclusivity right enshrined in some legal orders. The United States was the first country to adopt an extension of the exclusivity of patent rights to pharmaceuticals as an agreement between the industries of originators and generics after the effects of the Roche Products, Inc. v. Bolar Pharmaceutical Co. decision in $1984 .^{27}$ Shortly after the decision was rendered, declaring that the mere acts carried out to obtain the approval of a marketing authorisation by the competent

\footnotetext{
24 Accessible at: https://publications.europa.eu/en/publication-detail/-/publication/6e4ce9f8-aa41-11e7837e-01aa75ed71a1/language-en (accessed 2 January 2019).

25 Pages 2 and 3 of the study.

26 "With respect to the SPC export waiver to third countries, considering the impact on both EU-based innovators and generics and biosimilars, we estimate that in our base case scenario, it could result in net additional sales of $€ 7.3$ billion to $€ 9.5$ billion by 2025 for the EU-based pharmaceutical industry. These results translate into an EU manufacturing employment increase of $13 \%$ to $16 \%(20,000$ to 25,000 additional jobs), assuming no change in worker productivity. Additional savings in EU spending on pharmaceuticals of 4-8\% could materialise from a timelier introduction of generics and biosimilars in European markets following SPC expiry in Europe. These numbers are lower bounds as the effects are estimated on a sample of 117 non-biological and 17 biological molecules".

27 United States Court of Appeals for the Federal Circuit, 733 F.2d 858 (1984), judgment of 23 April 1984.
} 
authorities result in an infringement of the patent right, originator and generic industries reached a compromise known as the Drug Price Competition and Patent Term Restoration Act or Hatch-Waxman Act. ${ }^{28}$ This regulation introduced in the US legal system an extension of the patent term ${ }^{29}$ and a new exception based on the balance agreed in the pharmaceutical industry after the Bolar case (known thereafter as the Bolar exception). ${ }^{30}$

\subsection{The SPC as an Extension to Patent Exclusivity Based on Local Effects of the Delay in Obtaining a Market Authorisation for a Medicament}

It is not the object of this study to analyse the legal nature of the SPC in depth, but only in relation to the exception that has been proposed by the European Commission. $^{31}$

The SPC is an intellectual property right based on a general premise established in the Recitals of EC Regulation No. 1768/92: ${ }^{32}$ "at the moment the period that elapses between the filing of an application for a patent for a new medicinal product and authorization to place the medicinal product on the market makes the period of effective protection under the patent insufficient to cover the investment put into the research". Based on this, the European Community proposed "the creation of a supplementary protection certificate granted, under the same conditions, by each of the Member States at the request of the holder of a national or European patent relating to a medicinal product for which marketing authorization has been granted is necessary".

As the CJEU has reminded in a recent judgment of 25 July $2018,{ }^{33}$ the objective of the SPC is

to re-establish a sufficient period of effective protection of the basic patent by permitting the holder to enjoy an additional period of exclusivity on the expiry of that patent, which is intended to compensate, at least in part, for the delay to the commercial exploitation of his invention by reason of the time which has elapsed between the date on which the application for the patent was filed and the date on which the first MA in the European Union was granted. ${ }^{34}$

\footnotetext{
${ }^{28}$ Drug Price Competition and Patent Term Restoration Act. Public Law 98-417, of 24 September 1984.

29 Art. 35 U.S.C. 156, Extension of patent term. Not contemplated as a sui generis right, but as an extension of the term of exclusivity granted to the patent.

30 Art. 35 U.S.C. $\$ 271$ (e)(1) states that "it shall not be an act of infringement to [...] use [...] a patented invention [...] solely for uses reasonably related to the development and submission of information under a Federal law which regulates the manufacture, use, or sale of drugs".

31 For an in-depth analysis of the SPC regulation, see the exhaustive report commissioned by the European Commission in the Max Planck Institute for Innovation and Competition Report, elaborated by Hilty et al. (2018).

32 Council Regulation (EEC) No. 1768/92 of 18 June 1992 concerning the creation of a supplementary protection certificate for medicinal products, published in OJ L 182, 2 July 1992, pp. 1-5 and repealed by Regulation (EC) No. 469/2009 of the European Parliament and of the Council of 6 May 2009 concerning the supplementary protection certificate for medicinal products.

33 Court of Justice of the European Union, judgment of 25 July 2018, Teva UK Ltd and Others v. Gilead Sciences Inc., C-121/17, EU:C:2018:585.

34 Idem, para. 39 of the decision.
} 
So, the effect of the SPC is local, based on the specific circumstances of delays provoked by the necessity of obtaining marketing authorisation in Europe prior to launching a pharmaceutical product in a country of the European Union.

The CJEU also notes that Art. 4 of the SPC Regulation provides that the protection granted by the SPC extends only to the product covered by the MA granted for the corresponding medicinal product and for any use of the product as a medicinal product that has been authorised before the expiry of the SPC, exclusively "[w]ithin the limits of the protection conferred by the basic patent". This also applies regarding Art. 5 of the Regulation, under which the SPC is bound to the content of the basic patent. ${ }^{35}$

The SPC is thus a new and different IP right that can be subject to revocation according to the provisions contained in the SPC Regulation. ${ }^{36}$

\subsection{Non-applicability of the TRIPS Agreement to SPCs}

The Agreement on Trade-Related Aspects of Intellectual Property Rights, commonly known as TRIPS, was approved as Annex 1C of the Agreement establishing the World Trade Organization (WTO) and is mandatory for all WTO members. All the Member States of the European Union and the EU itself have signed the WTO Agreement and have to give effect to the provisions of TRIPS. ${ }^{37}$

It is established in the TRIPS Agreement that the term "intellectual property" refers to the categories that are the subject of Sections 1 through 7 of Part II. ${ }^{38}$ These categories are: (1) Copyright and Related Rights, (2) Trademarks, (3) Geographical Indications, (4) Industrial Designs, (5) Patents, (6) Layout-Designs (Topographies) of Integrated Circuits, and (7) Protection of Undisclosed Information. ${ }^{39}$ SPCs are not the object of regulation in the TRIPS Agreement. Therefore, they are not subject to the TRIPS Agreement. ${ }^{40}$

An extension of the patent term for pharmaceutical products based on the time needed to obtain marketing authorisation has only been adopted in some states. The first country to adopt Bolar-type legislation was the United States through the Patent Term Restoration Act of $1985 .^{41}$ Other countries that approved an extension for patents are South Korea in $1987,{ }^{42}$ Japan in $1988,{ }^{43}$ Australia in $1990,{ }^{44}$ Taiwan in

\footnotetext{
35 Idem, paras. 44 and 45 .

36 Some authors have expressed concerns that the TRIPS Agreement might be an issue, but without having deepened their justification. See Minssen, Kesselheim and Darrow (2019).

37 See Art. 1.1 of the Agreement.

38 See Art. 1.2 of the Agreement.

39 Articles 9 to 39 of the TRIPS Agreement.

40 In that same sense, see Seuba, Genovesi and Roffe (2017).

41 See supra note 27.

42 Art. 90 of the Korean Patent Act.

43 Art. 67(2) of the Japanese Patent Act.

44 Section 70 of the Patents Act 1990 provides for patent term extensions of up to five years in appropriate circumstances.
} 
$1994,{ }^{45}$ Israel in $1998,{ }^{46}$ Ukraine in $2000,{ }^{47}$ Belarus in $2002,{ }^{48}$ Russia in $2003,{ }^{49}$ and the CIS and Singapore in 2004. ${ }^{50}$ All these countries have approved a possible extension of the patent term up to a period of five years. Canada adopted an extension of the patent term up to a maximum of two years in 2016, after the trade agreement negotiated with the EU was signed. Apart from those states and the European Union, other states do not foresee in their domestic legislation the possibility of extending the patent term.

Thus, the TRIPS Agreement does not extend to SPCs or patent restoration terms and the member states are free to decide on whether they are regulated or not and with what terms and limitations.

\subsection{An Exception Justified and Consistent with Art. 30 TRIPS, Even When This is Only Applicable to Patents and Does Not Cover Other Intellectual Property Rights}

With the title of "Exceptions to Rights Conferred", Art. 30 of the TRIPS Agreement establishes the principles for the application of an exception to patent infringement: "Members may provide limited exceptions to the exclusive rights conferred by a patent, provided that such exceptions do not unreasonably conflict with a normal exploitation of the patent and do not unreasonably prejudice the legitimate interests of the patent owner, taking account of the legitimate interests of third parties".

Apart from what has been mentioned above about the application of the exception to the exclusive rights conferred by a patent, which do not include SPCs (indeed, as already mentioned above, SPCs are not a subject of regulation under TRIPS), Art. 30 of TRIPS is a translation to the realm of patents of the three-step test in the Berne Convention for the Protection of Literary and Artistic Works. ${ }^{51}$

According to Art. 30 of TRIPS, an exception to the exclusive rights conferred by a patent should comply with three conditions: (a) it has to be "limited", (2) it should not "unreasonably conflict with a normal exploitation of the patent", and (3) it should not "unreasonably prejudice the legitimate interests of the patent owner, taking account of the legitimate interests of third parties".

During the negotiation of the TRIPS Agreement, some countries tried to include specific exceptions that could be comprised within Art. 30. Finally, the text

\footnotetext{
45 Art. 53 of the Taiwanese Patent Act.

46 Patents Law, 5727-1967, § 64 J(1).

47 Art. 6 of the Ukraine Law on the Protection of Rights to Inventions and Utility Models.

48 Art. 1(3) of the Belarus Patent Law.

49 Art. 1363(2), Part IV of the Civil Code of the Russian Federation.

50 Section 36A of the Singapore Patents Act.

51 Adopted in 1886, the Berne Convention deals with the protection of works and the rights of their authors, Art. 9(2) on Right of Reproduction. Possible exceptions are stated: "It shall be a matter for legislation in the countries of the Union to permit the reproduction of such works in certain special cases, provided that such reproduction does not conflict with a normal exploitation of the work and does not unreasonably prejudice the legitimate interests of the author". See Hilty and Lamping et al. (2014): "Article 30 of the TRIPS Agreement constitutes an indivisible entirety. The 'three steps' are to be considered together and as a whole in a comprehensive overall assessment" (accessed 2 January 2019).
} 
approved was open to the inclusion of any circumstance that might comply with the three conditions established in that Article. ${ }^{52}$ The text adopted in the case of patents is similar to that approved for the exceptions to trademarks and copyrights. ${ }^{53}$

It has been interpreted that Art. 30 of the TRIPS Agreement does not require exceptions to be interpreted narrowly, but to be interpreted according to their objectives and purposes set forth in TRIPS Arts. 7 and 8. ${ }^{54}$ They do not unreasonably conflict with a normal exploitation of the patent if "they are based on important competing public policy considerations or have the effect of countering unreasonable impediments to the operation of markets (notably secondary markets)". 55

The export exception proposed by the Commission is intentionally addressed to comply with the conditions of Art. 30, although the TRIPS Agreement is not applicable to SPCs. ${ }^{56}$ The exception proposed by the Commission through its proposal of Regulation is limited as the SPC right is only restricted to making and other related acts for the purpose of exporting to third parties or preparing the launch on the same conditions as other makers producing in third countries. The exception proposed does not conflict with the normal exploitation of the patent as it will not have an impact in the country where the production is to be carried out during the period of exclusivity. The legitimate interests of the patent owner will not be unreasonably prejudiced either. On the contrary, the legitimate interests of third parties, the competitors and consumers, are appropriately protected by an exception

\footnotetext{
52 It can be tracked through the different statements formulated by the different countries during the long negotiations that resulted in the final text approved by the States. It is interesting to note the differences with the initial proposal of 29 March of 1990 of the European Communities: "Limited exceptions to the exclusive rights conferred by a patent may be made for certain acts, such as rights based on prior use, acts done privately and for non-commercial purposes and acts done for experimental purposes, provided that they take account of the legitimate interests of the proprietor of the patent and of third parties" (MTN.GNG/NG11/W/68, p. 10, Art. 24(2)).

53 Though there are important differences. Art. 13 on copyrights states that: "Members shall confine limitations or exceptions to exclusive rights to certain special cases which do not conflict with a normal exploitation of the work and do not unreasonably prejudice the legitimate interests of the right holder". Art. 17 on trademarks establishes that: "Members may provide limited exceptions to the rights conferred by a trademark, such as fair use of descriptive terms, provided that such exceptions take account of the legitimate interests of the owner of the trademark and of third parties".

54 See Declaration on Patent Protection. Regulatory Sovereignty under TRIPS, p. 15, mentioned at supra note 51. Cf. Canada - Patent Protection of Pharmaceutical Products, of 17 March 2000 (WT/DS114/R), where the report of the group ad hoc interpreted the word "limited" restrictively. The interpretations of special groups, as was the case in the opinion that has been cited, are not binding for the interpretation of the WTO and are not juridical precedents for subsequent cases (see Matsushita, Schoenbaum and Mavroidis (2006), p. 112.

55 Idem. The Declaration on Patent Protection was signed by 37 scholars, cited at p. 19 of the document mentioned at footnote 51 .

56 See the text of Recital 11 of the Regulation as proposed by the Commission: "By limiting the scope of the exception to making for the purpose of export outside the Union and acts strictly necessary for such making or for the actual export itself, the exception introduced by this Regulation will not unreasonably conflict with normal exploitation of the product in the Member State where the certificate is in force, nor unreasonably prejudice the legitimate interests of the certificate-holder, taking account of the legitimate interests of third parties" (finally and slightly modified as Recital 12).
} 
that provides certainty to the pharmaceutical industry producing in the European Union. $^{57}$

In any case, the limitation established in the exceptions in the TRIPS Agreement are only applicable to the rights explicitly regulated in that Agreement, specifically to patents in its Art. 30, and not to SPCs which are IP rights that are not the subject of that Agreement.

\section{Non-infringing Activities. Making and Related Acts to Export to Third Countries}

The main objective of the proposed legislation was the adoption of a specific exception to the exclusivity conferred to the certificate regulated by the SPC Regulation. The subject matter of the SPC is defined in Art. 4 of the Regulation. ${ }^{58}$ It is not an extension of the patent to which it refers, but only of the protection conferred to the product covered by an administrative authorisation to place it on the market as a medicinal product within the limits of the patent. The extension of the duration of protection conferred by an SPC has a local effect in the European Union, derived from the compromise reached by the European countries in 1992. ${ }^{59}$

The Commission proposed to modify the title of Art. 4, "Subject matter of protection", to "Subject matter of protection and exceptions to rights conferred" in order to include a reference to the manufacturing waiver. The title proposed referred to "exceptions", in plural, and not to "exception", thus suggesting the Commission was thinking about introducing more than one exception to export and consistent with the Recitals of the Regulation. ${ }^{60}$

The Parliament, unanimously, decided in several amendment proposals, that the manufacturing waiver should be incorporated into Art. 5, "Effects of the certificate", and not into Art. 4. The explanation was that "[c]oncerning its legal nature, the manufacturing waiver is an exception to the rights conferred by the certificate, and as such it should be placed in Article 5 of Regulation (EC) No

\footnotetext{
57 See Recital 6 of the Regulation proposed, where it is said that: "Without any intervention, the viability of the manufacture of generics and biosimilars in the Union could be under threat, with consequences for the Union's pharmaceutical industrial base as a whole".

58 Its current wording, contained in a single paragraph, is that: "Within the limits of the protection conferred by the basic patent, the protection conferred by a certificate shall extend only to the product covered by the authorisation to place the corresponding medicinal product on the market and for any use of the product as a medicinal product that has been authorised before the expiry of the certificate".

59 In this sense, see the Recitals of Council Regulation (EEC) No. 1768/92 of 18 June 1992 concerning the creation of a supplementary protection certificate for medicinal products, where it is explained that "a uniform solution at Community level should be provided for, thereby preventing the heterogeneous development of national laws leading to further disparities which would be likely to create obstacles to the free movement of medicinal products within the Community and thus directly affect the establishment and the functioning of the internal market".

${ }^{60}$ Cf. Recitals 7 and 8 of the amending Regulation.
} 
469/2009". ${ }^{61}$ Article 5 foresees that: "Subject to the provisions of Article 4, the certificate shall confer the same rights as conferred by the basic patent and shall be subject to the same limitations and the same obligations".

The specific acts under the exception that do not constitute an infringement of an SPC are included in Art. 5(2)(a). Article 5(2) introduces the exception in a first sentence which states that: "By way of derogation from paragraph 1 , the certificate referred to in paragraph 1 shall not confer protection against certain acts which would otherwise require the consent of the holder of the certificate ("the certificate holder'), if the following conditions are met". There are four conditions established in the Article, the first, letter (a), defining the specific activities that are subject to the exception and the other three, letters (b) to (d), establishing specific requirements of notifications, labelling and communications to third parties that the maker has to carry out in order to benefit from the exception proposed by the Regulation.

Letter (a) states that the acts comprise the making of a product, or a medicinal product containing that product for the purpose (i) of export to third countries or (iii) of storing it in the Member State of making in order to place it on the market of Member States after the expiry of the certificate and any related act that is strictly necessary for the making, in the Union, referred to in (i) and (iii) or for the actual storing itself. It implies not only that the acts carried out by the maker are included in the exception, but also those acts carried out by the maker itself or by third parties that are required either to enable the making or the export of the product made.

"Making" is the expression used in Art. 29 of the Community Patent Convention as one of the acts falling within the scope of exclusivity of a patent, ${ }^{62}$ Art. 7 of the Proposal for a Council Regulation on the Community Patent, ${ }^{63}$ and Art. 25 of the Agreement on a Unified Patent Court. ${ }^{64}$ In the same sense, there is also Art. 28(1) of the TRIPS Agreement, on the rights conferred by a patent. ${ }^{65}$ The exception should therefore cover the activity of making the product, "and the making of the medicinal product containing that product". 66 The making of the product was initially limited

\footnotetext{
61 Proposal of amendments 155 to 157 , published as $\operatorname{COM}(2018) 0317$ - C8-0217/2018 2018/0161(COD) and accessible at: http://www.europarl.europa.eu/sides/getDoc.do?type= COMPARL\&mode=XML\&language=EN\&reference=PE630.706. Accessed 31 March 2019.

62 Convention for the European Patent for the Common Market (Community Patent Convention 76/76/ EEC), published in OJEC, 26 January 1976, No. L 17 1-28: "A Community patent shall confer on its proprietor the right to prevent all third parties not having his consent: (a) from making, offering, putting on the market or using a product which is the subject-matter of the patent, or importing or stocking the product for these purposes".

63 Proposal for a Council Regulation on the Community patent, published as/* COM/2000/0412 final CNS 2000/0177*/in OJ C 337E, 28 November 2000, pp. 278-290. The texts of these provisions are the same as those of the Community Patent Convention.

64 Agreement on a Unified Patent Court, published in OJ C 175, 20 June 2013, pp. 1-40. The content of the Article is the same as those cited in the preceding footnotes.

65 This provision states that: "1. A patent shall confer on its owner the following exclusive rights: (a) where the subject matter of a patent is a product, to prevent third parties not having the owner's consent from the acts of: making, using, offering for sale, selling, or importing for these purposes that product".

66 Recital 10 of the Regulation.
} 
in the proposal of the Commission to a specific purpose, that of exporting the manufactured product to a third country. This limitation has disappeared in both the proposal of the European Parliament and that of the Council.

A second category of the acts included in the exception are those "strictly necessary for that making or for the actual export or the actual storing". Specific activities that would be covered by the exception are, for instance:

(i) Possessing, supplying, offering to supply, importing, using or synthesising an active ingredient for the purpose of making a medicinal product containing that product.

(ii) Temporary storing or advertising for the exclusive purpose of exporting to third-country destinations.

(iii) Related acts performed by third parties who are in a contractual relationship with the maker.

These acts are cited explicitly in Recital 9 of the amending Regulation. They are included as examples of activities that would be considered outside the scope of the rights conferred to the certificate holder.

There are some limits that Recital 11 clarifies that are not covered by the exception. Contrary to the above list of acts included in the exception, the negative list is a numerus clausus list. The acts included are as follows:

(i) Placing a product or a medicinal product containing that product on the market of a Member State, which is made for the purpose of export to third countries.

(ii) Storing a product or a medicinal product containing that product with a view to EU day-one entry on the market of a Member State where a certificate is in force, either directly or indirectly after export.

(iii) Re-importation of such a product or a medicinal product containing that product into the market of a Member State in which a certificate is in force.

(iv) Any act or activity for the purpose of import of products or medicinal products containing those products into the Union merely for the purposes of repackaging and re-exporting.

(v) Any storage of products or medicinal products containing those products for any purposes other than those set out in the Regulation.

Limitations (i), (iii) and (iv) were already cited by the Commission in the initial proposal. Numbers (ii) and (v) make reference to acts that were added in the final proposal of the European Parliament and Council and are intended to limit the possibility that products intended for export are finally re-imported with the aim of introducing them into the relevant market on day one or that the products are stored with an aim other than that set out in the Regulation.

The first limitation has to be interpreted in the sense that export to a Member State is permitted whenever an SPC has not been extended or is not in force in that country. Therefore, exporting to a third country means any country outside the European Union and any EU country where an SPC is not in force. Re-importation is equally tolerated if it is carried out after the expiry of the SPC. 
Finally, it is not permitted that a medicinal product made outside the European Union is imported into the states of the European Union just to be repackaged or reexported.

\section{Manufacturing to Enter into the EU Market Immediately After Expiry of the Relevant SPC, Limited to Six Months}

The Regulation proposed by the European Commission explains that:

A further unintended consequence is that the protection conferred by the certificate makes it more difficult for those manufacturers to enter the Union market immediately after expiry of the certificate, given that they are not in a position to build up production capacity until the protection provided by the certificate has lapsed, by contrast with manufacturers located in third countries where protection does not exist or has expired. ${ }^{67}$

This constraint places the European manufacturers (makers) of generics and biosimilars "at a significant competitive disadvantage compared with manufacturers [makers] based in third countries that offer less or no protection". ${ }^{6}$

In effect, as the Commission explained, the industry established in the European Union is not only prevented from manufacturing within Europe to export to third countries, but also to enter the market of the European Union right after the expiry of the SPC, on the same conditions as manufacturers established beyond the European borders. This harms the competitiveness of the European industry and, as dramatically highlighted in the text of the Commission, "the viability of the manufacture of generics and biosimilars in the Union could be under threat, with consequences for the Union's pharmaceutical industrial base as a whole". ${ }^{69}$ In this sense,

[i]ndirectly, it is also intended to put those manufacturers in a better position to enter the Union market immediately after expiry of the relevant supplementary protection certificate. It would also help to serve the aim of fostering access to medicines in the Union by helping to ensure a swifter entry

\footnotetext{
${ }^{67}$ Recital 4 of the Regulation was finally drafted as: "Likewise, makers are prevented from making generics and biosimilars for the purpose of storing them for a limited period before the expiry of the certificate. Those circumstances make it more difficult for those makers, in contrast to makers located in third countries where protection does not exist or has expired, to enter the Union market immediately after expiry of the certificate, given that they are not in a position to build up production capacity for the purpose of export or for the purpose of entering the market of a Member State until the protection provided by that certificate has expired".

68 Recital 5 of the Regulation, to which the European Parliament and the Council added what has already been mentioned at supra note 7 .

69 Recital 6 of the Regulation, where the European Parliament and Council added that: "That situation could affect the fully effective functioning of the internal market, through the loss of potential new business opportunities for makers of generics and biosimilars, thereby possibly diminishing related investments within the Union and hampering job creation within the Union”.
} 
of generic and biosimilar medicines onto the market after expiry of the relevant certificate. ${ }^{70}$

The report issued for the Commission added in Section 3.6 that:

A stockpiling exemption is likely to benefit the European generic and biosimilar pharmaceutical industry by allowing domestic producers to enter timely in markets where the SPC term of the reference product has expired, putting them on an equal footing to compete in these markets with generic and biosimilar producers located in markets without SPC protection (within as well as outside the EU). ${ }^{71}$

Specifically in relation to biosimilars, it is stated that: "A stockpiling exemption is likely to benefit EU-based biosimilars given the complexity of moving from manufacturing pilot batches to advance manufacture. [...] As discussed in section 4.5.3, the delay to enter markets following protection expiry is currently well in excess of 6 months for biosimilars". ${ }^{72}$ Not having such exception risks that "manufacturers located in countries where the protection has expired earlier or did not exist in the first place have an advantage in entering first upon protection expiry compared to e.g. domestic producers". ${ }^{73}$

The consequence is clear:

the combined effects of an SPC export waiver and a stockpiling exemption are likely to be mutually reinforcing, as domestic generic and biosimilar producers that have already set up large scale production to supply export markets will also be able to prepare stocks for timely entry upon domestic SPC protection expiry. $^{74}$

Additionally, it is also stressed that "a stockpiling exemption can be expected to result in a reduction in pharmaceutical expenditures by reducing delays in entry". 75

\footnotetext{
${ }^{70}$ Recital 8 of the Regulation, thoroughly redrafted by the European Parliament and the Council in the final text, includes a reference that: "This Regulation should also allow such makers to make and store products, or medicinal products containing those products, in a Member State for a defined period pending the expiry of the certificate, for the purpose of entering the market of any Member State upon expiry of the corresponding certificate, thereby helping those makers to compete effectively in the Union immediately after protection has expired ('EU Day-one entry'). This Regulation should also complement the efforts of the Union's trade policy to ensure open markets for makers of products, or medicinal products containing those products, established in the Union".

71 Pages 18 and 167.

72 Pages 19 and 173. It is also mentioned that the longer delay for biosimilars is "in large part due to the complexity of developing biosimilar products, however the delay has reduced over time" and that "ramping up production is more difficult for biosimilar producers due to the complexity of the production process".

73 Page 18.

74 Pages 19 and 181 .

75 Idem. This conclusion is also raised by other economic studies such as the "Study on the economic impact of supplementary protection certificates, pharmaceutical incentives and rewards in Europe", written by Copenhagen Economics and published by the European Commission in May 2018 at: https:// ec.europa.eu/health/sites/health/files/human-use/docs/pharmaceuticals_incentives_study_en.pdf, p. 33 (accessed 31 March 2019), where it was concluded as follows:
} 
Despite these explanations and the logic explained by the Commission, the initial proposal surprisingly did not include any specific provision that would permit the European industry to produce in the European Union "to enter the Union market immediately after expiry of the certificate".

It was a paradox that the Commission had taken care of the interests of third companies to which the products are given for the actual export so that they can reimport the medicaments exported once the SPC has expired ${ }^{76}$ but not of the producers themselves or the companies that can acquire the product in the European Union to introduce it into the market on that same date. The medicines can therefore be exported with the aim of being re-imported after the expiry of the SPC, but they cannot be stored in the European Union to be placed onto the European market after the certificate lapses. This was a contradiction.

The solution would have been as simple as providing in the initial Art. 4(2)(a)(i) that the certificate did not confer protection either to the "making for the exclusive purpose of export to third countries", or "to enter the Union market immediately after expiry of the certificate". These additional words would consist in the same terms contained in the Considerations for the proposal of the Regulation mentioned above.

The European Parliament and the Council noted the contradiction and were sensitive to the necessity of extending the manufacturing waiver to the European Union so that generic and biosimilar medicines could be introduced into the EU market on day one after the SPC expired. The proposal of the Commission was amended to complete the scope of the exemption during the parliamentary procedure and the final draft of Art. 5(2) (formerly Art. 4(2)) included a mention of

Footnote 75 continued

"The Bolar exemption at least partly remedied this. Following its enactment in 2004, generic companies are allowed to research generic products before the original patent (and potential SPC) has expired, without infringing the patent.

The Bolar exemption, however, only allows production of a patent-protected active ingredient for experimental use. This means that stockpiling, i.e. mass producing the medicinal product during the protection period, for immediate sale after end of said period is not allowed.

The effect of this is that generic producers can develop their generic version of a medicinal product even though it is patent-protected, but they cannot commence large-scale manufacturing in the EU until after the expiry of the patent.

Stockpiling while the product is protected by a patent (and SPC) in the EU might be possible in a nonEU country where less extensive patent protection rules are in place. However, production facilities outside the EU wishing to export products to the EU must comply with Good Manufacturing Practice (GMP), which ensures that imported products live up to EU quality standards.

This means that if a generic manufacturer wants to be able to market its product in the EU as soon as the patent protection period expires, there is an incentive to undertake the manufacturing outside the EU, in countries with less patent protection, unless adherence to the GMP rules prevent this".

76 Art. 5(9) (initially Art. 4(4)) of the amending Regulation establishes that: "The maker shall ensure, through appropriate and documented means, that any person in a contractual relationship with the maker who performs acts falling under point (a) of paragraph 2 is fully informed and aware of [...] (b) that the placing on the market, import or re-import of the product, or the medicinal product containing that product $[\ldots]$ could infringe the certificate referred to in paragraph 2 where, and as long as, that certificate applies". 
the making, no earlier than 6 months before the expiry of the certificate, of a product, or a medicinal product containing that product, for the purpose of storing it in the Member State of making, in order to place that product, or a medicinal product containing that product, on the market of Member States after the expiry of the corresponding certificate

as acts falling under the manufacturing waiver exception. ${ }^{77}$ In this regard, the European Parliament proposed including the day-one entry into the European Union in the draft Regulation, with a limitation on its applicability to two years before the expiry of the SPC, which was finally reduced to six months by the European Council. $^{78}$

Finally, on 20 February 2019 the Permanent Representatives Committee approved the proposal in line with that of the European Parliament but reduced the two-year term limitation to six months. ${ }^{79}$ There was no explanation about this restriction, which hinders the possibilities of the EU industry, but a provision regarding the evaluation to be carried out after five years speaks for itself:

[T]o evaluate the impact of the exception of making for the purpose of export, special account shall be taken of the effects of making for the purpose of storing in order to place that product, or a medicinal product containing that product, on the market of Member States after the expiry of the corresponding certificate, on access to medicines and on public health expenditure, and of whether the waiver and in particular the period provided for in point (a)(iii) of Article 5(2) is sufficient to achieve the objectives referred to in Article 5, including public health.

\footnotetext{
77 The preliminary conclusions of the Max Planck Institute for Innovation and Competition in its Final Report on the Study on the Legal Aspects of Supplementary Protection Certificates in the EU are that: "Manufacturing waivers in the form of export or stockpiling waivers are not precluded by TRIPS if they only apply to SPCs". (Hilty et al. 2018), p. 311.

78 On 23 January 2019, the Committee on Legal Affairs voted to include a further subparagraph (ia) to Art. 5(2)(a) to also exempt from the scope of protection of the SPC "making a product, or a medicinal product containing that product, for the purpose of storing in the Member State of making, during the final 2 years of validity of the certificate referred to in paragraph 1 , in order to place that product on the market of Member States as from day 1 after the expiry of the certificate in those Member States", and (iia) to "any act or activity for the purpose of import of medicinal products, or parts thereof, into the Union merely for the purpose of repackaging and re-exporting". The first limitation means introducing a dayone entry in the EU and the second makes clear that activities intended just for repackaging or reexporting are not covered by the exclusive right of the SPC. Recitals 7 to 11 are modified in the sense of including an application of the exception not only to exports but also to "entry into the EU market as from day 1 after the certificate has expired". See also the proposal of modification of Recital 20. The text was widely endorsed in the three committees that gave their opinion and finally approved by 21 votes in favour and two against. The limitation of two years was introduced by the JURI Committee, not by the other two committees, INTA and ENVI (Compromise amendments on the draft report on supplementary protection certificate for medicinal products 2018/0161(COD), available at: http://www.europarl.europa. eu/cmsdata/159901/juri-committee-voting-list-supplementary-protection-certificate.pdf (accessed 28 January 2019)).

${ }^{79}$ See the Proposal for a Regulation amending Regulation (EC) No. 469/2009 concerning the supplementary protection certificate for medicinal products as approved by the Permanent Representatives Committee on 20 February 2019 at: https://www.consilium.europa.eu/media/38246/st06638-en19. pdf (accessed 30 March 2019).
} 
The term of six months was mentioned in the economic studies published by the European Commission as the mean term of delay to enter into the territory of the EU after the expiry of an SPC. ${ }^{80}$ This means that at least the manufacture of half of the medicines will be penalised by this reduction to six months, especially biosimilars which need a longer period of manufacture. The term of two years proposed by the Parliament was more sensitive to the necessities of the European industry.

\section{Non-necessity and Deterring Effects of the Communication and Publication of the Commercial Intentions of the Manufacturer Foreseen in the Regulation}

The proposal for the Regulation not only provides for an exception to the acts of manufacturing for export. It establishes a specific regimen of safeguards, "in order to increase transparency, to help the holder of a certificate to enforce its protection in the Union and check compliance with the conditions set out in this Regulation and to reduce the risk of illicit diversion onto the Union market during the term of the certificate". ${ }^{81}$ In this regard, the text introduces up to three types of safeguards: (a) a special labelling of the product manufactured for export, (b) an obligation to inform clients, and (c) the obligation to make a communication to the certificate holder as well as to the corresponding patent offices with certain information of the maker that will be published.

We analyse each of these safeguards, whether they are appropriate to achieve the objectives of the Regulation and what their effects are on the manufacturers that will benefit from the exception.

\subsection{Labelling to Export}

The proposal for the Regulation imposes labelling requirements on the maker

in order to facilitate, by means of a logo, identification of such products or such medicinal products as being exclusively intended for the purpose of export to third countries. Making for the purpose of export and related acts should only fall within the scope of the exception if the product, or the medicinal product containing that product, is labelled in the manner provided

\footnotetext{
${ }^{80}$ As the Charles River study (see supra note 23) explains, "the entire delay in generic and a large part of the delay in biosimilar entry is the result of preparing for large scale production" (p. 152), and: "We used a 6 month period as a delay as biosimilars tend to enter with a longer delay compared to generics, due in part to the longer development times" (p. 198, footnote 351). Likewise, in the same study: "If, as a result of the SPC export waiver, biosimilars in Europe entered with a 6-month delay (relative to 1 year delay without an SPC export waiver) following SPC protection expiry in Europe, we estimate savings on pharmaceutical expenditures of $€ 0.6$ billion for the sample of molecules examined or a $2 \%$ saving" (p. 15). As for biosimilars, it was added that: "For biosimilars there is a longer delay to enter following protection expiry, in large part due to the complexity of developing biosimilar products, however the delay has reduced over time. A stockpiling exemption can be expected to also benefit biosimilar producers, as ramping up production is more difficult for biosimilar producers due to the complexity of the production process" (p. 19).

81 Recital 13 of the Regulation.
} 
in this Regulation. This labelling obligation would be without prejudice to labelling requirements of third countries. ${ }^{82}$

In this sense, letter (d) of Art. 5(2) foresees that "the maker ensures that a logo, in the form set out in Annex I, is affixed to the outer packaging of the product, or the medicinal product containing that product, referred to in point (a)(i) of this paragraph, and, where feasible, to its immediate packaging" as a condition of the exception to making for the exclusive purpose of export to third countries. The logo, included in Annex 1 to the amending Regulation, to be affixed to the outer or immediate packaging of the product, would be inserted in this form:

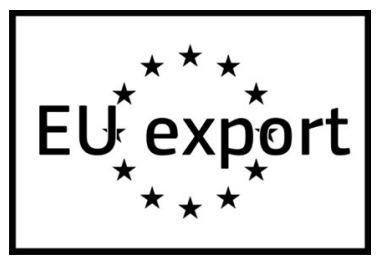

This condition, as noted from the corresponding Recital mentioned above, has the aim of facilitating the identification of the product as covered by the exception. This provision entails a presumption that every product including the logo should fall outside the SPC protection. Other products not labelled as indicated in the Regulation will in principle not fall under the exception, unless an appropriate reason is given by the manufacturer (for instance, if the product has not been packaged yet or the outer packaging is commissioned to a third company).

\subsection{Obligation to Inform Clients}

The Regulation establishes that the makers will have to

inform persons within its supply chain in the Union, including the exporter and the person carrying out the storing, through appropriate and documented means, in particular contractual means, that the product, or the medicinal product containing that product, is covered by the exception provided for in this Regulation and that the making is intended for the purpose of export or storing. A maker who fails to comply with those due diligence requirements should not benefit from the exception, nor should any third party performing a related act in the Member State of making or in a different Member State in which a certificate conferring protection for the product is in force. The holder of the relevant certificate would therefore be entitled to enforce its rights under the certificate, while having due regard to the general obligation, provided for in Directive 2004/48/EC of the European Parliament and of the Council, not to engage in abusive litigation. ${ }^{83}$

\footnotetext{
82 Recital 21 of the Regulation.

83 Recital 20 of the Regulation.
} 
This means that the persons who are bound contractually with the maker in its supply chain will have to be informed by the maker. In the case that the latter does not comply with that obligation, it will not benefit from the exception. This includes both the exporter and the person doing the storing in order to launch on day one after the SPC expiry in the Member States. Recital 9 of the Regulation lists possible related acts, which could include "possessing; offering to supply; supplying; importing; using or synthesising an active ingredient for the purpose of making a medicinal product or temporary storing or advertising for the exclusive purpose of export to third-country destinations" and related acts performed by third parties that are in a contractual relationship with the maker.

As explained above, persons having a contractual relationship with the maker can be suppliers, clients, or subcontractors. A supplier of the manufacturer could be the manufacturer of the active pharmaceutical ingredient or API, or of an intermediate of that API; a client could be a manufacturer of the medicament or a distributor of the medicament; and a subcontractor could be the person or company that carries out activities such as storage, packaging or transport.

The obligation of information established in the Regulation is aimed at informing those within the supply chain of the maker or downstream. The maker of a pharmaceutical product does not have to inform the API manufacturer as the former receives the product from the latter or from a trader. If the API was protected by the SPC, the API manufacturer or trader will have to inform its client or clients in the territory of the SPC. The subcontractors who carry out any related act not included in the supply chain (packaging or storage) or who cannot dispose of the product (transporters or customs brokers) do not seem to be the recipients of the information. The subcontractors in this case will not have the capacity to place the medicament on the market, import or re-import it. Therefore, there is no need for these subcontractors to be informed that those acts might infringe the SPC. They will not be in a position to carry out any of the activities that are the subject of the limits established in the Regulation.

The EU Regulation suggests in the above-mentioned Recital 20 that as appropriate and documented means we can understand "in particular contractual means". It is therefore advisable in contracts with third parties to include clauses relating to compliance with the communication obligations laid down in the Regulation.

The distributors or the clients of the maker with the capacity of placing on the market, importing or re-importing the medicament are the subjects of the supply chain that are the addressees of the duty of information foreseen in the Regulation. In this case, the maker of the product protected by the SPC will have to inform the distributor or client that the medicament is exclusively for export to third countries and that should it be placed, imported or re-imported to the country where, and as long as, the SPC applies, it might constitute infringement. ${ }^{84}$

\footnotetext{
84 An example of a clause valid in this context could be: "The Client is informed of the existence of the Supplementary Protection Certificate No. [Number] in [Country] and that the Medicament has been manufactured with the exclusive purpose of export to third countries. Placing the Medicament on the market, importing or re-importing it within the territory of the EU might infringe that SPC".
} 


\subsection{Obligation to Provide State Authorities and the SPC Holder with Certain Information and Publication of the Communication}

The last condition established as a safeguard in the amending Regulation proposed by the Commission and accepted by both the European Parliament and the Council consists in providing the authorities and the SPC holder with certain information of the activity that the maker intends to carry out. The text approved explains that:

This Regulation should impose an information obligation on the maker, namely the person established in the Union, on whose behalf the making of a product, or a medicinal product containing that product, for the purpose of export or storing, is carried out. It is possible that the maker directly carries out the making. That information obligation should consist of requiring the maker to provide certain information to the competent industrial property office, or another designated authority, which granted the certificate ("the authority") in the Member State where the making is to take place. A standard form for notification should be provided for this purpose. The information should be provided before the making of a product, or a medicinal product containing that product, starts for the first time in that Member State, or before any related act prior to that making, whichever is the earlier. It should be updated as and when appropriate. The making of a product, or a medicinal product containing that product, and the related acts, including those performed in Member States other than the one of making in cases where the product is also protected by a certificate in those other Member States, should only fall within the scope of the exception where the maker has sent the notification to the authority of the Member State of making, and where the maker has informed the holder of the certificate granted in that Member State. Where making takes place in more than one Member State, a notification should be required in each of those Member States. In the interests of transparency, the authority should be required to publish, as soon as possible, the information received, together with the date of notification of that information. ${ }^{85}$

Article 5(2) of the text approved by the Council establishes in its letter (b) that

the maker, through appropriate and documented means, notifies the authority referred to in Article 9(1) of the Member State in which that making is to take place, and informs the certificate holder, of the information listed in paragraph 5 no later than three months before the start date of making in that Member State, or no later than three months before the first related act, prior to that making, that would otherwise be prohibited by the protection conferred by a certificate, whichever is the earlier. ${ }^{86}$

\footnotetext{
85 Recital 14 of the Regulation.

86 The information listed in paragraph 5 of Art. 4 consists in: the name and address of the maker; the purpose of the making; the Member State in which the making, the first related act prior to that making or the storing is to take place; the number of the SPC; and for medicinal products to be exported, the reference number of the marketing authorisation or the equivalent in each third country of export as soon as it is publicly available.
} 
The interest in the communication does not lie in the mere fact that the patent office is informed. It is established in a new paragraph 4 of Art. $11^{87}$ that: "The authority referred to in Article 9(1) shall publish, as soon as possible, the information listed in Article 5(5), together with the date of notification of that information. It shall also publish, as soon as possible, any changes to the information notified in accordance with point (c) of Article 5(2)". This implies that the notification is published and therefore disclosed to third parties, and competitors will have knowledge of the intentions of the maker before it begins to produce the medicament protected by the SPC (the communication is made three months prior to the making, ${ }^{88}$ while the initial proposal of the Commission foresaw a shorter term of 28 days less 15 days in which the communication had to be published).

The proposal of Regulation foresees that "in the interests of transparency" the authority that receives the communication is required "to publish, as soon as possible, the information received, together with the date of notification of that information". 89 The initial proposal of the Commission foresaw that the publication was also requested "for the purpose of informing the holder of the certificate of the maker's intention". This last justification was suppressed in the text of the proposal of the Council since a direct notification to the SPC holder was added to the proposal.

It is at least questionable that the effect of the publication fulfils the necessities derived from those two interests and there is no explanation at all on what those interests consist of and what kind of necessity fulfils the communication. There is no evaluation at all of the necessity or the pros and cons of the communication in terms of competitiveness.

The information required in the communication is of a confidential nature. ${ }^{90}$ The identity of the manufacturer and the sites of manufacture are protected by EU law and are expressly considered as confidential by the health authorities of the European Union. ${ }^{91}$ It is established that the names of manufacturers or suppliers of

\footnotetext{
87 Art. 11 of the Regulation establishes the regimen of publication of an SPC. This new paragraph 4 is added to the three already existing.

88 Art. 5(2)(b) of the Regulation.

89 Recital 14 of the Regulation.

90 Directive 2016/943 on the protection of undisclosed know-how and business information (trade secrets) against their unlawful acquisition, states in its Recital 2 that: "Businesses, irrespective of their size, value trade secrets as much as patents and other forms of intellectual property right. They use confidentiality as a business competitiveness and research innovation management tool, and in relation to a diverse range of information that extends beyond technological knowledge to commercial data such as information on customers and suppliers, business plans, and market research and strategies". Directive (EU) 2016/943 of the European Parliament and of the Council of 8 June 2016 on the protection of undisclosed know-how and business information (trade secrets) against their unlawful acquisition, use and disclosure (Text with EEA relevance), OJ L 157, 15 June 2016, pp. 1-18.

91 The HMA/EMA recommendations on transparency. Recommendations on release of information with regard to new applications for medicinal products before and after opinion or decision on granting of a marketing authorisation (published in November 2010, EMA/484118/2010) establish that: "EMA and National Competent Authorities should have a common approach on what should be considered as commercially confidential, in particular whilst procedures to assess marketing authorisation applications are ongoing. In view of the lack of a legal definition and for the purpose of harmonisation "commercial confidential information' shall mean any information which is not in the public domain or publicly
} 
the active substance or the excipients are confidential, unless disclosure is necessary for public health reasons, as well as those of other manufacturers involved in the procedures. $^{92}$ This information is known by the health authorities but kept confidential to third parties as commercially sensitive and valuable. The principle of transparency has indeed been invoked in the past to approve rules in Europe compelling the Member States to supress unnecessary administrative barriers in the course of trade. ${ }^{93}$

On the other hand, the necessity of establishing such safeguards does not seem to be justified. There is no risk of an SPC infringement since a medicament cannot be placed onto the European market without previously having obtained marketing authorisation from the corresponding national or European health authorities. A medicament that is manufactured in the European Union must necessarily have obtained previous administrative approval where there will be information on the applicant as well as on the identity of the manufacturer of the medicament if it is located in the European Union. If a medicament that had been manufactured in the European Union were to be introduced or re-imported in the territory of one of the Member States, it would be known by the SPC holder as the marketing authorisation would inform of this fact. ${ }^{94}$ There is therefore no risk that the medicament is placed

\section{Footnote 91 continued}

available and where disclosure may undermine the economic interest or competitive position of the owner of the information". The HMA/EMA Guidance Document on the identification of commercially confidential information and personal data within the structure of the marketing authorisation (MA) application - release of information after the granting of a marketing authorisation (HMA/EMA Working Group on Transparency, adopted in principle by HMA on 23 February 2012, formally adopted by written procedure on 9 March 2012, and edited on 14 March 2012) states clearly that the manufacturers of (a) the medicinal products, and (b) the active substances and the sites of manufacture constitute commercially confidential information.

92 HMA/EMA Working Group on Transparency, Sects. 1, 3.1.1, 3.4, and HMA/EMA Guidance Document on the identification of commercially confidential information and personal data within the structure of the marketing authorisation (MA) application, Sects. 1.2.5.2, 1.2.5.3, 1.5.6, 1.5.8, 1.5.10, 1.5.22, 1.9, 3.2.S.2, 3.2.P.3 (both cited in supra note 91).

93 The Bolkestein Directive (Directive 2006/123/EC of the European Parliament and of the Council of 12 December 2006 on services in the internal market, OJ L 376, 27 December 2006, pp. 36-68) which compels the Member States to eliminate restrictions on cross-border provision of services, while at the same time increasing transparency and information for consumers, would give consumers wider choice and better services at lower prices (Recital 2 of the Directive). The communication contemplated in the amending Regulation does not provide transparency within the meaning of the interests of consumers, but on the contrary damages the interests of the makers in relation to their competitors and orders the disclosure of especially sensitive commercial information of their business plans to competitors in third countries that are not obliged to provide that information.

94 According to Art. 2 of Regulation (EC) No. 726/2004 of the European Parliament and of the Council of 31 March 2004 laying down Community procedures for the authorisation and supervision of medicinal products for human and veterinary use and establishing a European Medicines Agency (published in OJ L 136, 30 April 2004, pp. 0001-0033): "The holder of a marketing authorisation for medicinal products covered by this Regulation must be established in the Community. The holder shall be responsible for the placing on the market of those medicinal products, whether he does it himself or via one or more persons designated to that effect". Art. 9 of Regulation (EC) No. 726/2004 specifies in Title V of Directive 2001/83/EC of the European Parliament and of the Council of 6 November 2001 on the Community code relating to medicinal products for human use (published in OJ L 311, 28 November 2001, pp. 67-128) what concerns the contents of the labelling and package leaflet. Art. 8(2) of Directive 2001/83/EC establishes that: "A marketing authorization may only be granted to an applicant established in the 
on the European market or re-imported as in any case this information would necessarily be public and known by the SPC holder beforehand. ${ }^{95}$

In fact, none of the exceptions that have been recognised for third parties in the patent laws requires any communication to the patent office from the person who carries out acts falling within the scope of the patent claims. There is no link between the patent holder and the person who benefits from the application of an exception. The mere obligation to disclose information which will be communicated to the patentee about the acts that the competitor intends to carry out implies the exercise of a control on the independent activity of a competitor. The request for a communication about the commercial intentions of the non-infringer is not foreseen in relation to any of the following exceptions: (a) private and non-commercial use; (b) experimental use; (c) pharmacists' preparations; (d) prior use; (e) farmer privilege; (f) Bolar clause; and (g) parts for means of transport - vehicles, trains, ships, aircrafts. The situation is different for persons linked to the patentee by (a) a commercial licence; (b) a compulsory licence; or (c) exhaustion of a right or parallel commerce.

In conclusion, the introduction of the safeguards as they were initially proposed would have harmed the competitiveness of the European generic and biosimilar manufacturers compared to manufacturers established in third countries where the identity of the manufacturers and the site of manufacture, the date of manufacture of the APIs or medicines, as well as the countries to which the manufacturer has the intention to export, is information that is held as confidential and is not disclosed to the SPC holder or competitors. This caused the European Parliament to propose a wide reformulation of the safeguard system in its Report of January 2019, limiting the object of the communications and suppressing publication. ${ }^{96}$

\section{Footnote 94 continued}

Community", and Art. 26(3) that: "The applicant or the holder of a marketing authorisation shall be responsible for the accuracy of the documents and the data submitted". Art. 8(3) of Directive 2001/83/EC establishes that the application of a marketing authorisation for a medicament shall be accompanied among other particulars by the name or corporate name and permanent address of the applicant and the qualitative and quantitative particulars of all the constituents of the medicinal product, including the reference to its international non-proprietary name (INN) recommended by the WHO or a reference to the relevant chemical name. According to Art. 59(1), the package leaflet shall be drawn up in accordance with the summary of the product characteristics and shall include the name and address of the manufacturer. It is understood by "manufacturer in Europe" importers of medicinal products coming from third countries that are able to carry out manufacture in compliance with the particulars supplied pursuant to Art. 8(3)(d) - description of the manufacturing method, and/or to carry out controls according to the methods described in the particulars accompanying the application in accordance with Art. 8(3)(h) description of the control methods employed by the manufacturer.

95 By contrast, if the medicament is the API manufactured for export, this information will remain confidential in third countries, where the information of the suppliers of the pharmaceutical company that will market the product in the country will not have to be disclosed. If this information had to be communicated to the patent office and published, this would have a negative effect on the possibilities of European manufacturers, as their intentions would be exposed to the originator and to competitors, either of generics or biosimilars.

96 On 23 January 2019, the Committee on Legal Affairs proposed that the communication of the maker that the making is to take place (a) should be notified at least two months before the starting date of making, (b) directly to the maker on a confidential basis, without confidential information in this case, (c) is not published, and (d) is used only to certify whether the requirements of the Regulation have been 
The final text proposed by the European Council in its draft, approved on 20 February 2019 and passed by the European Parliament on 17 April 2019, foresees that the maker notifies the competent authority of the Member State where the making takes place through a common form annexed to the Regulation as well as the SPC holder no later than three months before the start of making or of the first related act. It is provided that any changes to the information shall be notified to both the competent authority and the SPC holder. With regard to the publication, the authority shall publish, as soon as possible, the information to be notified by the maker, together with the date of receipt of the notification of that information and any changes to this information. In relation to the initial proposal of the Commission, the information to be notified is limited to (a) the name and address of the maker; (b) an indication of whether the making is for the purpose of export, for the purpose of storing, or for the purpose of both export and storing; (c) the Member State where the making and, if applicable, also the storing is to take place and the relevant Member State where the first related act, if any, prior to that making is to take place; (d) the number of the certificate granted in the Member State of making, and the number of the certificate granted in the Member State of the first related act, if any, prior to that making; and (e) for medicinal products to be exported to third countries, the reference number of the marketing authorisation or equivalent in each third country of export, as soon as it is publicly available.

It seems from Recital 14 of the text proposed by the European Council that not only the first related act has to be notified to the authority and the SPC holder, but also any related act in any Member State where an SPC is in place. ${ }^{97}$ According to Recital 15, the information notified is limited to what is "necessary and appropriate" for the SPC holder to assess if its rights are respected, and "should not include confidential or commercially sensitive information", which is consistent with EU Directive 2016/943. ${ }^{98}$

\footnotetext{
Footnote 96 continued

accomplished. It is proposed in Art. 11 that only the mention of the number of the certificate which the notification affects is to be published by the relevant national authorities, which will take appropriate measures to preserve the confidentiality of the information notified by the prospective maker. It also agreed on 23 January 2019 to (a) make reference in b) to "Member State" instead of "address, or addresses of the premises", (b) substitute in letter c) the mention of "relevant Member State" for "Member State of making", and (c) suppress letter d), in relation to the mention of the number of authorisations granted to the maker (Compromise amendments on the draft report on supplementary protection certificate for medicinal products 2018/0161(COD), available at: http://www.europarl.europa. eu/cmsdata/159901/juri-committee-voting-list-supplementary-protection-certificate.pdf (accessed 28 January 2019).

${ }^{97}$ Recital 14 provides that "The making of a product, or a medicinal product containing that product, and the related acts, including those performed in Member States other than the one of making in cases where the product is also protected by a certificate in those other Member States, should only fall within the scope of the exception where the maker has sent the notification to the authority of the Member State of making, and where the maker has informed the holder of the certificate granted in that Member State".

${ }^{98}$ See supra note 88.
} 


\section{Entry into Force of the Regulation. Necessity that the Manufacturing Waiver Is Applied to Non-infringing Activity Rather than to Granted SPC Rights}

In the initial proposal of the Commission, the amending Regulation established that only certificates granted on or after the date of the first day of the third month that follows the month in which the amending Regulation would be published would benefit from the exception. ${ }^{99}$ The applicability of the manufacturing waiver was linked to the necessity that the specific SPC was granted after the entry into force of the Regulation. This meant that the exception would not have been applicable to any SPC already granted. Therefore, the manufacturing exception would not have accrued the benefits estimated by the Commission.

In other words, the expectations of the European industry of generics and biosimilars would have been frustrated for several years and the threat to the viability of manufacturing generics and biosimilars in the Union, with consequences for the Union's pharmaceutical industrial base as a whole, would not have been dispelled.

The reasons for this delay in the application of the Regulation were explained in Recital 19 as initially proposed by the Commission. The European Parliament and the Council changed the content of this Recital substantially. ${ }^{100}$

None of the reasons provided in the text of the amending Regulation was supported by any study or data. On the contrary, as mentioned above, these assertions contradict the fact that the application of the exception will not unreasonably conflict with normal exploitation of the product in the Member State where the certificate is in force, nor unreasonably prejudice the legitimate interests of the certificate-holder.

The situation, on the contrary, as the Commission contended in the Recitals of the proposed Regulation, is that the absence of such an exception would put at risk the pharmaceutical industry located in the European Union. As explained in Recital 7 of the Regulation proposed by the Commission, this was aimed: (a) to ensure that manufacturers established in the Union are able to compete effectively in thirdcountry markets where supplementary protection does not exist or has expired, (b) to put those manufacturers in a better position to enter the Union market

\footnotetext{
99 A new Art. 4(5) was proposed in the Regulation in terms of establishing to which certifications the exception would be applicable: "Paragraph 2 shall apply in the case only of certificates granted on or after [OP: please insert the date of the first day of the third month that follows the month in which this amending Regulation is published in the Official Journal)]". Finally, this sentence was modified and included as the first sentence of Art. 5(10) with the following content: "Paragraph 2 shall apply to certificates that are applied for on or after ... [the date of entry into force of this amending Regulation]". Art. 2 of the amending Regulation establishes that the Regulation "shall enter into force on the twentieth day following that of its publication in the Official Journal of the European Union".

100 The reasons given by the Commission were as follows: a) not to deprive the SPC holders of their acquired rights, (b) to allow the applicants a reasonable time to adjust to the changed law context and to make appropriate investment and manufacturing location decisions in a timely way, and (c) to allow sufficient time for public authorities to put in place appropriate arrangements to receive and publish notifications (see Recital 12 of the Regulation). The assertion that the SPC holders need time "to adjust to the changed legal context and to make appropriate investment and manufacturing location decisions" was a mere sentence void of support in the text of the Regulation and contrary to the real effects that the exception will have.
} 
immediately after expiry of the relevant SPC, and (c) to serve the aim of fostering access to medicines in the Union by helping to ensure a swifter entry of generic and biosimilar medicines onto the market after expiry of the relevant certificate.

The text finally approved by the Parliament and the Council changed substantially from that suggested by the Commission in its initial proposal and advanced the date of application to 2 July 2022 and to any certificate that takes effect as from the entry into force, which was 1 July 2019, therefore being effective three years after the entry into force of the Regulation. ${ }^{101}$

\subsection{Different Criteria Applied to the Entry into Force of Other Exceptions to Patents Introduced by the European Union in the Past, Even to SPCs Themselves}

If we revisit the EU legislation that has been approved in the past in relation to the application of exceptions to patent law, we realise that the regime of delay in the application of the manufacturing waiver in the amending Regulation differs from the implementation of exceptions or limitations to patents. The exceptions foreseen so far are intended to overcome limitations that are detrimental to the interests of the individuals affected. This is the case for the Bolar provision, the farmer privilege, compulsory cross-licensing between plant variety holders and patent holders or compulsory licences on patents for generics for export to countries with public health problems.

When the Bolar provision was approved in Europe in 2004 through Art. 10(6) of Directive 2004/27/EC, ${ }^{102}$ it applied to the activities to obtain the corresponding authorisations to place generic or biosimilar products on the market. That European Directive did not subject the application of the exception to patents or SPCs that were approved after the entry into force of the Directive. The exception was applicable to the activities carried out by third parties and foreseen by that exception. Countries implemented the Directive in their corresponding patent laws and none of them deferred the application of the exception to intellectual property rights that were granted until the entry into force of the exception. If this had been the case, the Bolar provision would not have been applicable until recent times.

\footnotetext{
101 This is foreseen in Art. 5(10), second and third sentences ("Paragraph 2 shall also apply to certificates that have been applied for before 1 July 2019 and that take effect on or after that date. Paragraph 2 shall only apply to such certificates from 2 July 2022. Paragraph 2 shall not apply to certificates that take effect before 1 July 2019"), and is explained in Recital 26, according to which it "should ensure that the exception is applied, on a progressive basis," to any SPC that takes effect after it enters into force so that "[s]uch application of the exception would allow the holder of a certificate that has been granted, but that has not yet taken effect by the date of the entry into force of the Regulation, a reasonable period of transition to adapt to the changed legal context, while at the same time ensuring that makers of generics and biosimilars can benefit effectively, without excessive delay, from the exception".

102 Directive 2004/27/EC of the European Parliament and of the Council of 31 March 2004 amending Directive 2001/83/EC on the Community code relating to medicinal products for human use, published in OJ L 136, 30 April 2004, pp. 34-57. Art. 10(6) of the Directive foresees that: "Conducting the necessary studies and trials with a view to the application of paragraphs 1,2,3 and 4 and the consequential practical requirements shall not be regarded as contrary to patent rights or to supplementary protection certificates for medicinal products".
} 
In 1998 the European Communities approved a Directive on biotechnological inventions. ${ }^{103}$ One of the situations that represented a novelty in the European law of the Member States was the exception to patent infringement known as the farmer privilege. It had been strongly debated during the discussions before the European Parliament and finally approved as an authorisation to use the product of the harvest for further multiplication or propagation on the farmer's own farm, although this activity objectively falls within the scope of the patent and constitutes an infringement. ${ }^{104}$ The Directive did not defer the applicability of that exception in the law of the Member States. The applicability of such exceptions was the same as for the other provisions established in that regulation.

In the same regulation of biotechnological inventions, compulsory cross-licensing between plant variety holders and patent holders was foreseen in the field of exploitation of new plant characteristics resulting from genetic engineering or use of plant varieties in genetic engineering, in order to guarantee access by means of a compulsory licence and subject to a fee. The EC Directive did not establish any limitation in relation to rights already granted. As in the case of the farmer privilege, the limitation to patent rights was established for any existing patent or plant variety.

Finally, in relation to patents, in 2006 the European legislative bodies established by means of an EU Regulation the possibility of obtaining compulsory licences of patents for generics for export to countries with public health problems. ${ }^{105}$ Once again, the applicability of this limitation was not reserved to patents that had not been granted when the Regulation entered into force. Otherwise, even today, 12 years after the approval of that Regulation, the possibility of obtaining a compulsory licence would still not be applicable in the territory of the Member States.

Even with regard to the creation of the SPC, the fact that the patent offices must put in place appropriate arrangements to receive, examine, grant and publish the SPCs was not considered a problem for the immediate application of the Regulation.

Article 23 of the SPC Regulation approved in $1992^{106}$ established that this would be applicable six months after its publication and would be binding in its entirety

\footnotetext{
${ }^{103}$ Directive 98/44/EC of the European Parliament and of the Council of 6 July 1998 on the legal protection of biotechnological inventions, published in OJ L 213, 30 July 1998, pp. 13-21.

${ }^{104}$ Art. 11 of Directive 98/44/EC states as follows: "1. By way of derogation from Articles 8 and 9, the sale or other form of commercialisation of plant propagating material to a farmer by the holder of the patent or with his consent for agricultural use implies authorisation for the farmer to use the product of his harvest for propagation or multiplication by him on his own farm, the extent and conditions of this derogation corresponding to those under Article 14 of Regulation (EC) No 2100/94. 2. By way of derogation from Articles 8 and 9, the sale or any other form of commercialisation of breeding stock or other animal reproductive material to a farmer by the holder of the patent or with his consent implies authorisation for the farmer to use the protected livestock for an agricultural purpose. This includes making the animal or other animal reproductive material available for the purposes of pursuing his agricultural activity but not sale within the framework or for the purpose of a commercial reproduction activity. 3. The extent and the conditions of the derogation provided for in paragraph 2 shall be determined by national laws, regulations and practices".

105 Regulation (EC) No. 816/2006 of the European Parliament and of the Council of 17 May 2006 on compulsory licensing of patents relating to the manufacture of pharmaceutical products for export to countries with public health problems, published in OJ L 157, 9 June 2006, pp. 1-7.

${ }^{106}$ Council Regulation (EEC) No. 1768/92 of 18 June 1992 concerning the creation of a supplementary protection certificate for medicinal products, published in OJ L 182, 2 July 1992, pp. 1-5.
} 
and directly applicable in all Member States. The SPC Regulation did not include any provision that the SPCs would only be granted on the basis of patents obtained after the date the Regulation entered into force. ${ }^{107}$

When paediatric extensions were created in 2006 through an amendment of EC Regulation $1768 / 92$ on SPCs, ${ }^{108}$ the legislators did not establish any limitation to its application in relation to SPCs already granted. On the contrary, a specific regimen for the entry into force of the Regulation was established to allow SPCs already granted to benefit from paediatric extensions, and special provisions were approved to allow SPC holders to apply for such extensions in extended terms after the entry into force of the Regulation of 2006. ${ }^{109}$

The precedents of the legislative initiatives of the European Union show that it was never considered to defer the applicability of a certain limitation or exception to a patent right. Even the application of the SPCs was not restricted to patents that had not yet been granted. The SPCs could be granted based on any existing patent.

\subsection{What Interests Do a Deferred Application of the Exception Serve?}

The proposed amendment does not affect the content of the SPC right, its granting, existence or scope of protection of the intellectual property right created by the Regulation. ${ }^{110}$ The proposed amendment in fact addresses, as explained in the Recitals of the proposed Regulation, the unintended practical consequences of the SPC system. ${ }^{111}$ These unintended effects are of a practical nature in the manufacturing activities of the European industry of generics and biosimilars. The entry into force of the new Regulation should therefore affect the activity that is the object of the exception, i.e. the making of medicaments that fall within the scope of a certificate.

The SPC is granted exclusively to compensate for the delay in the launch of a medicament derived from the necessity of obtaining administrative authorisation to place the product on the market in the Community. Accordingly, the SPC Regulation is linked to that local effect and should not affect the activity of EU producers with regard to other territories. As we have already seen, the manufacturing waiver has no impact on the exclusivity rights granted to the SPC holder in the territories where an SPC has been granted and is in force. The

\footnotetext{
107 The Regulation only provided a delay in certain States whose laws had introduced the patentability of pharmaceutical products only recently before the Regulation was passed. Art. 21 provided that: "In those Member States whose national law did not on 1 January 1990 provide for the patentability of pharmaceutical products, this Regulation shall apply five years after the entry into force of this Regulation".

108 Regulation (EC) No. 1901/2006 of the European Parliament and of the Council of 12 December 2006 on medicinal products for paediatric use mentioned at supra note 21.

109 New paragraphs were added to Art. 7 of the SPC Regulation: "4. The application for an extension of the duration of a certificate already granted shall be lodged not later than two years before the expiry of the certificate", and " 5 . Notwithstanding paragraph 4, for five years following the entry into force of Regulation (EC) No 1901/2006, the application for an extension of the duration of a certificate already granted shall be lodged not later than six months before the expiry of the certificate".

110 As has already been mentioned, this is acknowledged in Recital 12. See supra note 56.

111 As indicated in Recitals 4, 5, and 6.
} 
manufacturing waiver does not elude the application of the enforcement directives in case of infringement. ${ }^{112}$ On the contrary, if the application of the amending Regulation were deferred, the impact in the generic and biosimilar industry would be enormous. ${ }^{113}$ This has also been the conclusion of the European Parliament, which proposed that the manufacturing exemption be applied to those SPCs for which the basic patent expired on or after 1 January $2021,{ }^{114}$ and that of the Council, which, as analysed above, finally proposed 2 July 2022 as the date of applicability to those certificates that were applied for before the entry into force of the amending Regulation and that will take effect on or after it entered into force on 1 July 2019.

\section{Conclusions}

The new Regulation, which amends the Regulation concerning SPCs for medicinal products, introduces an exception to overcome the limitations of the European pharmaceutical industry so that it can compete equally with companies located beyond the European Union borders. The manufacturing exception complements the Bolar provision approved in 2004 and includes - limited to the SPCs - the exemption that the European Parliament proposed in 2002 for patents and SPCs. The Member States will have to decide whether they introduce a similar exception in their domestic patent laws.

The exception under study has two main objectives: to ensure open markets for Union-based manufacturers of medicinal products and to ensure a swifter entry of generic and biosimilar medicines onto the market after expiry of the relevant certificate. The text passed by the Commission contemplated the possibility of exporting to third countries (even to companies that would re-import medicaments into European markets after the expiry of the corresponding SPCs), but did not foresee that the European producers would themselves introduce their own

\footnotetext{
112 See Recital 23 of the amending Regulation.

113 Medicines for Europe published a document entitled "Comparison of expiry dates of protection worldwide", where it compared the situation of the protection conferred to 109 products in the EU, USA, Korea, China, India and Canada. In all the cases the protection conferred in Europe expired later than in Canada, India and China. It expired in Europe later than in the USA in $88 \%$ of the cases (97 against 12) and Korea in $94 \%$ of the cases (103 against 6), file://Users/mvq/Documents/ $2 . \% 20$ Note $\% 20$ on $\% 20$ SPC $\% 20$ manufacturing\%20waiver\%200ct\%202017.pdf (accessed 3 August 2018). In a non-published study carried out by AESEG, considering the difference between the expiry date in Europe and in the United States in non-biological medicines that in 2017 had sales over USD 400 million (in number 25 molecules), the market that will not be accessible to European generic manufacturers if the exception for exports is not applicable rises to USD 109.29 billion.

114 On 23 January 2019, and in relation to the date on which the patent expires, the Committee on Legal Affairs voted to modify paragraph 5 of Art. 4 and Recitals 21 and 22 accordingly, in the sense that the exception contemplated in paragraph 2 "shall apply to certificates that are applied for on or after the entry into force of this Regulation. It shall also apply in the case only of certificates for which the basic patent expired on or after 1 January 2021". Compromise amendments on the draft report on supplementary protection certificate for medicinal products 2018/0161(COD), available at: http://www. europarl.europa.eu/cmsdata/159901/juri-committee-voting-list-supplementary-protection-certificate.pdf (accessed 28 January 2019).
} 
production into the European market without exporting it to third parties. A day-one launch provision was missing in the text. The Parliament and the Council resolved this shortfall by providing that the making that falls under the exception should not only be restricted to the exclusive purpose of export to third countries, but also encompass that carried out during the six months before the expiry of the SPC for the purpose of storing the product or the medicinal product containing that product in the Member State of making in order to place it on the market of a Member State after the expiry date.

Perhaps the most important aspect that would have made the Regulation proposed ineffective for at least ten years was paragraph 5 of Art. 5 (initially Art. 4), which would have made the legislation proposed inapplicable to SPCs already granted. All studies carried out by the Commission concerning the effects of the exception would have been useless. The opportunity for European manufacturers would have been lost for products affected by SPCs due to lapse even after 2030. Fortunately, this delay, which would have frustrated the expectations of the European manufacturing industry, was revised and modified by both the Parliament and Council, which finally reached an agreement to make the exception applicable after a period of three years.

As far as the safeguards are concerned, which do not exist in other exceptions established in the law in relation to patents, the impression is that the Commission did not carry out a thorough analysis of the real risks that might arise if the manufactured products were launched or re-imported into the SPC countries before the expiry of the SPC and has now over-reacted. The reasons pointed out in the text, such as transparency or reduction of illicit diversion of medicaments onto the European Union market, are not supported by facts and arguments. On the contrary, it harms the competitiveness and potential business opportunities of European manufacturers of generics and biosimilars. Once more, the Parliament and the Council have agreed in the necessity of limiting the number of requirements to the generic or biosimilar makers.

With the amendments carried out in the text of the Regulation by the Parliament and the Council that have been commented on in this study, the limits and bounds of the new exception introduced in the SPC Regulation will be closer to meeting the expectations placed in this important modification of the current Regulation on SPCs, key to the future of the EU-based generic and biosimilar industry.

Open Access This article is distributed under the terms of the Creative Commons Attribution 4.0 International License (http://creativecommons.org/licenses/by/4.0/), which permits unrestricted use, distribution, and reproduction in any medium, provided you give appropriate credit to the original author(s) and the source, provide a link to the Creative Commons license, and indicate if changes were made.

\section{References}

Benkard G. (1981) Patentgesetz, Gebrauchmustergesetz. Continued by Ballhaus W, Bruchhausen K, Rogge R, Ullmann E. Beck Verlag, Munich

Charles River Associates (2016) Assessing the economic impacts of changing exemption provisions during patent and SPC protection in Europe. https://publications.europa.eu/en/publication-detail/-/ publication/6e4ce9f8-aa41-11e7-837e-01aa75ed71a1/language-en. Accessed 2 Jan 2019 
Copenhagen Economics (2018) Study on the economic impact of supplementary protection certificates, pharmaceutical incentives and rewards in Europe. Published by the European Commission in May 2018. https://ec.europa.eu/health/sites/health/files/human-use/docs/pharmaceuticals_incentives_ study_en.pdf. Accessed 31 March 2019

De Jongh T, Radauer A, Bostyn S, Poort J (2018) Effects of supplementary protection mechanisms for pharmaceutical products. Published by the Technopolis Group on 15 June 2018. http://www. technopolis-group.com/wp-content/uploads/2018/06/2718-Technopolis-report-on-supplementaryprotection-mechanisms.pdf. Accessed 31 March 2019

Hilty R et al (2018) Study on the legal aspects of supplementary protection certificates in the EU. Final report. Max Planck Institute for Innovation and Competition. Published by the European Commission. https://ec.europa.eu/docsroom/documents/29524/attachments/1/translations/en/.../pdf. Accessed 3 Aug 2018

Hilty R, Lamping M et al (2014) Declaration on patent protection. Regulatory sovereignty under TRIPS. Published by the Max Planck Institute for Innovation and Competition. https://www.mpg.de/ 8132986/Patent-Declaration.pdf. Accessed 2 Jan 2019

Matsushita M, Schoenbaum TJ, Mavroidis PC (2006) The World Trade Organization, 2nd edn. Oxford University Press, Oxford

Minssen T, Kesselheim AS, Darrow JJ (2019) An export-only exception to pharmaceutical patents in Europe: should the United States follow suit? Nat Biotechnol 37(1):21-22

Seuba X, Genovesi M, Roffe P (2017) A manufacturing for export exception. In: Mercurio B, Kim D (eds) Contemporary issues in pharmaceutical patent law: setting the framework and exploring policy options. Routledge, Abingdon. Available at: https://papers.ssrn.com/sol3/Data_Integrity_Notice. cfm?abid=2745802. Accessed 2 Jan 2019

\section{Cases}

European Commission v. Moravia Gas Storage AS, Court of Justice of the European Union, judgment of 26 March 2015, C-596/13, EU:C:2015:203

Funkuhr II, German Federal Supreme Court (Bundesgerichtshof), judgment of 30 January 2007, case X ZR 53/04, 2007 GRUR 307

Roche Products, Inc. v. Bolar Pharmaceutical Co., United States Court of Appeals for the Federal Circuit, judgment of 23 April 1984, 733 F.2d 858 (1984)

Teva UK Ltd and Others v. Gilead Sciences Inc., Court of Justice of the European Union, judgment of 25 July 2018, C-121/17, EU:C:2018:585

WesternGeco LLC v. ION Geophysical Corp., United States Supreme Court, judgment of 22 June 2018, No. 16-1011, 585 US (2018), 138 S. Ct. 2129 (2018)

Publisher's Note Springer Nature remains neutral with regard to jurisdictional claims in published maps and institutional affiliations. 